\title{
THE ICONOGRAPHY OF JOHN FORD'S WESTERNS
}

\author{
IRINA CHIRICA \\ Alexandru Ioan Cuza University of Iași, Romania
}

\begin{abstract}
This paper follows the way in which the filmography of the movie director John Ford presents cultural icons. We discuss the symbolism of these images and their cultural significance in the larger context of the West as a cultural area and American culture in general. Ford's sensibility had one foot in 19th century American thought and feeling, and the other in the 20th century. We argue in favor of the idea that John Ford is a mythbuilder and a visual image-maker whose contribution provided the foundation of a romantic, heroic America and the forging of American national character.
\end{abstract}

Keywords: American West, cultural icon, frontier, patriotic landscape, John Wayne

A cultural icon is a conventional traditional image encoded with generally accepted significance, identified by members of a culture as representative of that culture. When people perceive a cultural icon, they relate it to their general perceptions of the cultural identity it represents. The experience of sharing these images acts as a force of social cohesion, because these images express value judgments that everyone is expected to endorse. Cultural icons contain a symbolism that is instantly recognized by all members of society, no matter what their social rank or education might be. Cultural icons are connected to identity because they remind members of a social group who they are and supports the way they see themselves, endorsing ideas regarding what is acceptable and commendable in social life.

Cultural icons define a common sense of the past shared by the members of a certain culture. They are the construction bricks of traditional order and the main form in which knowledge of the past operates in society. They can be renewed and transformed in order to reflect cultural development. They evolve in step with the ideology that supports them and they are reshaped by the evolution of ideology and taste (Smith 17). Myths speak through iconic images 
rather than through words. Words classify and separate, while images synthesize meaning in a way that interrelates and unifies. When the images of myth acquire special cultural significance and general recognition, they become cultural icons. When these images reveal the way of seeing and the basic attitude of a nation, they become emblems of national experience and help us understand the nature of that nation's sensibility. The Western, with its cultural icons, explains America to us and helps us understand it.

The movie director John Ford was one of America's major mythbuilders and visual image-makers, one of the most important shapers of the West as a myth. Painters, photographers and movie-makers are responsible for the creation of a national landscape and "a national aesthetic." The western movie genre has been a primary creator of cultural icons. And John Ford was perhaps the greatest western movie director. His westerns celebrate the epic American migration across the landscape of the AmericanWest, the quest for the Promised Land, the cavalry and the stagecoach, life on the frontier, the Indian attacks and wagon trails and the building of the Transcontinental Railroad. For Ford, the conquest of the frontier was the American epic, the nation's creation myth.

John Ford's westerns are about the building of America and the birth of the American nation. He came with epic visual narratives which tapped into deep feelings that lie at the foundation of American identity. As a filmic historian, he was without equal, and he uplifted the myth of America to grand proportions. His large scope movies have a staggering visual poetry and dramatic spectacle of grand proportions. His sensibility had one foot in 19th century American thought and feeling, and the other in the 20th century sensibility. The characteristic ingredients of a John Ford western are that he gave the tough world of the traditional western a chivalric and sympathetic atmosphere. He hardly has shoot-out and violent scenes and his characters are realistic, humorously presented and humanized for the mass audience.

Ford prefers to depict common people. "However humble and uneducated, common people possessed a sympathetic social instinct and moral intuition that tell them right from wrong. Indeed, some liberals thought that plain unlettered people had a stronger moral sense than educated gentlemen, in the tradition of Thomas Jefferson" (Wood, 10). Ford's movies are built on this fundamental assumption The democratic articulation of the characters and their journey in Stagecoach in particular could be interpreted as upholding the ideas above. Ford "expands our understanding of basic American folk characters such as the silent hero, the hard-drinking but essentially romantic professional, the whore with a heart of gold, the lovable and somewhat pathetic old retainer, the righteous father, the meek who shall inherit the earth etc" (Kaminsky 203).

A good example of Ford's sweeping frontier scenes is the Dakota Land Rush, represented in the silent movie Three Bad Men (1926). The Oklahoma 
Land Rush and the Dawes Act of 1889 opened for settlement unassigned lands left vacant in the post-Civil War period. These lands were considered some of the best unoccupied public land in the nation. In reality it was a subterfuge for transferring Indian land into white hands. Most of the land had belonged to the Indian reservations. The movie includes a long land rush scene in which hundreds of competitors are waiting for the sound of the cannon to rush for the free land into unsettled territory. The tension of the people waiting, then the mad race presents panoramic views interlocked with details of individuals, balancing the story of the nation with individual tales. A famous scene is that of a baby abandoned during the stampede of horsemen and carriages. The baby is snatched from the ground by a rider's hand at the last moment before being run down by the incoming mad horses and wagons. Ford tells the American saga in human terms and makes it come alive in unforgettable iconic images that provided the foundation of a romantic, heroic America and the forging of American national character. He is always "an idealist and a sentimentalist when it comes to people and society” (Darby 282).

Ford started his career in the silent film era, when he directed dozens of movies. It was the silent western that first introduced the epic element in his work. The Iron Horse (1924) chronicles the building of America's first transcontinental railroad after the Civil War. The film has recently been printed on DVDs and was made accessible to the public. Ford regards the railroad as a symbol of successful unification after the Civil War.

The Iron Horse is a hymn to Manifest Destiny and the building of America. The movie tells how the first transcontinental railroad was built. Constructions gangs start from both coasts rejecting Indian attacks, thwarting greedy landowners, initiating a sweeping trail drive and moving whole towns along the line. Cattle drives, Indian attacks, land rushes, buffalo hunters... "It is a film of arresting parts rather than a whole”, shows Jim Kitses in Horizons West (Kitses 43). After battles against blizzard and the desert, the film's hero finally avenges the murder of his father and wins the hand of the woman he loves. The hero is in search of the mythical paradise of "The Promised land" and in search of revenge, because his father was killed by the Anglo villain in coalition with the Indians.

The story culminates with the scene of the driving of the golden spike at Promontory Summit on May 10, 1869. The meeting of the two teams is used by Ford to symbolize peace-making and national forgiveness after the Civil War, through a sacred moment of national coming together and creation. Ford studied the photographs taken at the driving of the golden spike and his movie recreates these photos with great accuracy. There are many moments in the movie that have this detailed photographic accuracy. "Iron horse" is the Indians' name for the locomotive. But the Iron Horse of the title can be interpreted as a cultural icon primarily signifying progress and civilization. 
John Ford was consciously building the image of the train (The Iron Horse) capitalizing on John Gast's well-known painting, American Progress (1872), in which a luminous feminine figure in white robes with the Star of Empire in her forehead is leading the pioneers from East to West, accompanied by a train, telegraph poles and a trail of covered wagons. The idea of American Progress was connected to the concept of "Manifest Destiny", first presented in 1845 by John L. O'Sullivan, who claimed that America had been divinely chosen by God to bring the light of civilization across the American continent. This concept defined the rapid westward expansion of civilization and continued to strongly influence the American way of thinking in John Ford's time.

Ford persevered in representing trains as icons of progress in The Man Who Shot Liberty Valance (1962). The movie begins and ends with the image of a train entering (and exiting) Shinbone, Texas. Senator Ransom Stoddard (Jimmy Stewart) travels by train to bring progress and civilization out West. Following Horace Greeley's invitation to “Go West, Young man!”, as a young lawyer, Ransom headed out to the great frontier of America, hoping to establish a law practice in a territory not yet officially accepted as a state. But on the way his stagecoach was held up by the infamous bandit Liberty Valance (Lee Marvin), and Ransom was badly beaten when he tried to defend a lady who was being robbed. His law books were torn and trampled derisively by the bandits.

The young lawyer comes West with a bagful of law books, but no gun. $\mathrm{He}$ is an idealist who naively believes in improving his country, a man who dreams of turning the desert into a garden, a man who believes in the power of civilization. His solid moral principles are doubled by a strong will. But Ranse is utterly vulnerable and exposed in the Wild West, because he cannot use a gun. It will be Tom Doniphon (John Wayne) who will shoot the bad man, allowing Ranse to unknowingly take credit (Ranse shot his gun at the same moment, without hitting the target). The point that the movie makes is that you cannot stop the advance of progress and ultimately, the man with the law book wins (and takes the girl) and the man with the gun dies away forgotten in the shadow (Tom Doniphon). And the train brings progress.

The border of the frontier is not fixed, it is advancing constantly westwards. The westering process produced a succession of frontiers, from the Appalachians to the Pacific. The wilderness beyond the frontier, the realm of savagery, was a constantly receding area. As shown by the historian Frederick Jackson Turner, the frontier was the ideal place for the building of uniquely American qualities. The successive Wests provided the "free" land on which equality and democracy were able to flourish. In settling the frontier, people created a democracy.

The first clumsy steps of democracy in the West are satirically described Ford's movie, The Man Who Shot Liberty Valance. For example, election takes place in a saloon, its signboard barely covered by the announcement "Mass 
Meeting Elections", and the voters are so unruly and rowdy that only the gunman Tom Doniphon can make order. The voters are more intrigued by the fact that the bar is closed than they are interested in voting. When the election is over, they all stampede to the bar. Later, the county elections look like a rodeo when a horse is brought on stage and made to drink beer, and the Rangers' candidate, Buck Langhorne (it sounds like the bovine Long Horn) who looks like a Mexican vaquero, has rope tricks played over his head.

One of the best things in this western that it successfully foils John Wayne and James Stewart. Ranse Stoddard struggles to "improve" life through education and law, while Tom still relies on his gun. But although their approaches are different, the two protagonists stand up against the outlaw mentality of the odious Liberty Valance, with respect for each other.

But the West is changing, the frontier is waning and the gunfights of yore turn into legend. And the irony of the film is that the politician is rendering the gunslinger obsolete. Eventually, you cannot win the battle with a gun, a situation similar to that in Stephen Crane's famous short story "The Bride Comes to Yellow Sky", in which the outlaw Scratchy Wilson cannot help withdrawing in front of the puzzling estate of matrimony, and the man without the gun ironically wins the battle without the expected shoot-out). The train also features prominently in Stephen Crane's story, where it practically takes the first part of the text.

Interesting to notice, in painting and cinematography trains and wagon trails always move from the right to the left (corresponding on a map to a movement from the East to the West), as a reflection of the deeply ingrained idea of the frontier's westward movement. Trains always bring progress and sometimes they may have a negative impact on the environment, but you cannot expect Ford to represent this aspect in his cinematography. He prefers to embrace the traditional views of a benign technology graciously embraced by the American landscape.

Another iconic image that we need to mention is the stagecoach. Considered the first great American western in American cinematography, the movie Stagecoach (1939) revitalized Hollywood's attitude towards Westerns. We could say that Stagecoach is a foundational movie in the western genre. It is a masterpiece. Ford builds the story around a group of richly portrayed characters who are on a stagecoach set to leave Tonto (the Town of Dimwits) with the destination Lordsburg (God's Fortress). The stagecoach is the backbone of the movie, the device that brings everything together. It can be compared to a Ship of Fools, in which all social categories are represented: the corrupt banker, the town doctor (also the town drunk), the sheriff who rides shotgun, the prostitute with a heart of gold, the officer's wife, the gambler (the fallen Southern aristocrat), the outlaw, the stagecoach driver, etc. These people rally together in the face of the elements and Indian attacks, in a "democratic" manner 
that equalizes social classes and even develops "the cult of the outlaw" (Slotkin 278). The expansive scale of the landscape, the overwhelming outlines of Monument Valley and the ageless character of the rock formations evoke the ordeal of the frontier experience.

Virtually all of Ford's films, including his westerns, reflect the use of old photographs and paintings by the masters. While Ford claimed that he just walked on the set and placed his actors by sheer instinct, it is clear that he had a remarkable visual memory for authentic or seemingly authentic historical scenes that he had seen in other media. The chase of the stagecoach and the final attack are classic American moments. For example, for most people the name Stagecoach brings to mind the spectacular pursuit of the stagecoach across the salt flats by the attacking Apache, culminating in the classic last-minute rescue by the cavalry. In this context, the stagecoach becomes an outpost of civilization holding on against savagery in the Wild West.

Stagecoach first introduced Monument Valley in the American western genre. Situated on the Arizona-Utah border at an elevation of over 4000 feet, Monument Valley belongs to the Navajo Indians. In 1938, Harry Goulding and his spouse (who were running a trading post in Monument Valley), drove to Hollywood with a portfolio of photographs. Goulding talked his way in to see Ford, showed him the pictures, and convinced him to make Stagecoach in Monument Valley. Ford was impressed when he saw the photos and immediately went there to explore the site. He was totally taken in by Monument Valley's epic sweep, its mythical feeling of age and legend and the gigantic proportions of the rock outcroppings. The larger than life atmosphere makes people appear diminutive by contrast, outlining the enormous effort of men pitted against nature. It is a spectacular place characterized by extreme temperatures and monumental rock formations sticking out of the ground. Going on location there was a remarkable accomplishment in the 1930s and 1940s. Ford was impressed by the primeval character of the landscape and he liked the isolation of the place - the fact that there was no possibility of interfering telephones and no competition for his position as an authority figure.

Ford shot ten of his most famous films in Monument Valley, starting with Stagecoach. Monument Valley offered the ultimate frame for Ford's pictures - sandstone buttes puncture the earth like fists, and delicate architectural spires rise toward the sky. At night clouds descend and settle over the buttes and pillars like God visiting creation. Ford's films are visually distinctive. He was a great pictorial artist. A Ford movie is an aesthetic pleasure, a visual gratification. It always has stunningly beautiful images. He painted a picture in movement, in action in still shots. He always had a keen eye for beauty, skillful at framing scenes in a painterly manner. He was a genuine master of framing, montage, composition and mise-en-scene. It is therefore no wonder that he was totally taken in by the grandeur of Monument Valley. 
The breathtaking Monument Valley was to become "the signature landscape of Ford's westerns and the iconic image of the American West" (Goetzmann 340) Stark abysses, brilliant ascents, impassable terrains which remind us of nothing so much as of our dreams. Ironically, American settlers never came through the valley, but because of Hollywood, the territory has become synonymous with the Old West, symbolizing in the minds of his compatriots (and in the mind of people all over the world), the heroic conquest of the American continent.

The mythical West provided the perfect symbol for Americans to rally around when confronted by national threat: The Great Depression and World War II. This explains the popularity of westerns in these periods. The Western provided the unifying myth in an era when national crises demanded consensus. It demonstrated that Americans could succeed if they remained true to the spirit of the Old West. Like mythical westerners, Americans had to retain their selfreliance, independence and sense of mission by connected to the moral code represented by the West.

And occasionally, it has been part of what has given rise to defensive and reactionary responses - certain forms of nationalism, sentimentalized recovering of a sanitized "tradition". The West is the most strongly imagined section of the United States. A state of mind rather than a region, the West depends on the cultural baggage of the beholder. Few came to discover what there was to see in the real West. Rather they came with ideas about what they hoped to find. The mythical West imagined by Americans has shaped the West of history just as the West of history has helped create the West Americans imagined. The two cannot be neatly severed. People's intentions and actions are often shaped by cultural myths.

Images of progress and images of national landscape that dramatize the American national identity in sweeping cinematic vistas. The Grand Canyon, Yosemite, Monument Valley are iconic American places associated with the idea of American Bigness. Americans delight in telling foreigners that they have for example the largest, the tallest and the oldest trees in the world. The most massive tree is one of the California big trees, a sequoia called "General Sherman.” It is the largest tree on Earth and has enough timber to make 5 billion match sticks. Americans also have the largest canyon on earth, the Grand Canyon, which is a mile deep. The American nation is one of the mightiest nations of the world, stretching over a continent. It is not surprising, therefore, that Americans have the tendency to emulate what we could call "American Bigness". John Ford's imagery developed on an already existing background. When they watched his movies, Americans saw the reflection of the mythical thinking already existing in their minds.

The more we look at the way in which Ford pictured western experience, the more we realize that history and myth is in the eye of the 
beholder. Politicians, philosophers, painters, photographers and cinematographers are premier myth makers who shape the way in which Americans see themselves, building upon the bedrock foundation of the images that are already implanted in the national subconscious. Ford's films capitalize on the relationship existing between the American West and American cultural memory, mixing stories of heroism with the mythical forging of the American nation through the confrontation with the wilderness. Ford places the West at the center of American history and character, paying tribute to the westerners and pioneers who built the country.

As Peter Cowie shows in John Ford and the American West, Westerners are seen as part of a lineage that conquered a wilderness and transformed the land, springing from a people who carved out their own destiny and remained beholden to no one, with an absolute belief in individualism. In the imagination of modern America, the West has come to stand for independence and self-reliance. The western landscape is regarded as the proving ground of character. It is austere and dry, a place which is inimical to well-being, where man is exposed and there is no place to hide, defined by the absence of vegetation, water and shadow. This kind of landscape will necessarily produce a type of character that is larger than life and tough.

The towering mountains, bleak deserts and vast plains have produced in popular mythology - an exceptional western character that is particularly rugged and resourceful, open and honest but ready to remonstrate and fight when it is necessary. Big skies, endless prairies, striking scenes - the most austere, unspoiled landscape on the face of the earth, identified with the presence of God. Western mythology has constructed a western character to match the dramatic scenery of the West.

As Stuart Kaminsky shows in American Film Genres, it is no wonder that the West has been traditionally envisioned and codified as predominantly male and white. The Hollywood western until the 1970s accepted racial supremacy as a rule, romanticizing chauvinistic masculinity. This convention will only be questioned beginning with the revisionist westerns of the 70s.

We could say that John Ford fathered the best-known image of the westerner - John Wayne (Gallagher 313). In real life, Ford and Wayne has a father-son relationship. Wayne was to Ford what David was to Michelangelo his masterpiece. Wayne was thirty-one years old when Ford distributed him in the main role in Stagecoach (1939). Until then he had appeared in B westerns without distinguishing himself. The problem was that B Westerns frequently asked Wayne to project emotions outside of his range, so Ford's decision to cast John Wayne in the role of the Ringo Kid met with serious objections. Before Stagecoach, Wayne's characters projected a boyish charm, but often looked inept when scenes demanded real acting ability. But the more the producers objected, the more Ford fought for his decision to keep Wayne. 
Ford understood Wayne's limitations as an actor and created a role Ringo Kid - that could use Wayne's greenhorn talents. He showed Wayne that his characters were at their best when he used only a minimum of words. Ford taught Wayne that being a Western star depended as much upon what you don't say as on what you say. John Wayne's characters are always men of few words. In Stagecoach, Ford frequently simply focuses the camera on Wayne's face. But whereas a B-Western director might ask Wayne to show surprise or fear or anger, Ford evoked from him much subtler reactions. Ford taught Wayne that to express himself through his eyes, not through his verbosity, as he had done before in the B Westerns. Western heroes do not have the large vocabularies an expensive education can buy. They don't have time to read books. People who talk too much are victims in westerns.

Wayne is a closed being, similar to a fortress. It is a matter of selfcontrol. Underplaying is essential to the cool, competent western hero, who gives nothing away. As Jane Tompkins has shown in West of Everything, "the male, by remaining hermetic and closed up, maintains the integrity of the boundary that divides him from the world” (Tompkins 56). Perhaps the most notable aspect of the western hero is his effort to maintain an inexpressive - so entirely self-contained is John Wayne, that he seems to exist entirely beyond conversation. To be a man is to be "monolithic, silent, mysterious, impenetrable as a desert butte, it is to be the desert butte" (Tompkins 57).

We may argue that the Western genre rejects the feminine very strongly. The explanation could be that women and their language remind men of their own inner problems, from which they want to escape. Women's talk evokes a suffocating network of familial and social relationships. Men run away in westerns from the cluttered Victorian interior, from the domestic dramas that go on in that setting, and from the emotional entanglements that cannot be dealt with. In American culture there is a male tradition of hardy independence from the tyranny of the petticoat, starting with Washington Irving's "Rip Van Winkle" and continuing with Jack London, Ernest Hemingway, Norman Mailer and beyond.

John Wayne represented for Americans their national image - the tough, courageous and strong honorable man who stood up to evil, defending the basic values of the country. He stood for an America that people felt was slowly vanishing. But despite his reputation as a role model and a father figure - he performs fatherly and avuncular duties in more than 25 westerns - his "professional hero" status does not allow him to be a good family man. Eventually, the western hero cannot settle down without becoming less than he is. He cannot be "tamed" by a woman, without losing a part of his masculinity. The lone rider rides into the sunset, nostalgically embracing the untamed West of the past and chooses male freedom rather than family responsibility and feminine values. 
In this paper, we have focused on some of the most significant cultural icons in John Ford's cinematography, demonstrating how John Ford's symbolism functions within an encoded system of metaphors representative for the American myth of the West. Ford's westerns function as mythical narratives dramatizing themes of national identity. Ford's West was the embodiment of a promise, it was a land of dreams where people's potential could be built and identity could be carved out of the breath-taking, unspoiled Western territory.

The West reflects the American experience not so much as it really was but as how Americans would like it to be. A myth is an encoded set of metaphors with a central function central in the societies that produced them. Myths give meaning to the world. In this sense a myth about the West is a story that explains who westerners (and Americans) are helps establish their identity. It speaks directly to American ideals, values, needs and goals. It combines other American beliefs involving national purpose, individual freedom, success and the superiority of the common people. Anyone who seeks to understand the United States has first to understand the story of the West.

\section{References}

Cowie Peter, John Ford and the American West. Harry Abrams Inc. Publishers, New York. 2004. Print.

Darby, William. John Ford's Westerns. McFarland \& Company Publishers, Jefferson North Carolina, 1996. Print.

Goetzmann, William. The West of Imagination. University of Oklahoma Press, 2009. Print.

Kaminsky, Stuart. American Film Genres. Chicago: Nelson Hall, 1984. Print.

Kitses Jim, Horizons West. Directing the Western from John Ford to Clint Eastwood, BFI Publishing, 2004. Print.

Slotkin, Richard. Gunfighter Nation: The Myth of the Frontier in Twentieth-Century America. University of Oklahoma Press, 1992. Print.

Smith, Henry Nash. Virgin Land: the American West as Symbol and Myth. Harvard University Press, 1970. Print.

Tompkins, Jane. West of Everything. The Inner Life of Westerns, Oxford University Press, New York, 1992. Print.

Wood, Gordon. The Empire of Liberty. Oxford University Press. 2009. Print.

\section{BIONOTE}

Irina Chirica is specialized in American Studies - history, ethnicity, visual arts history of the United States. She holds a PhD with the research paper - Aspects of Time in 20th Century American Novel. She has visited the US on several occasions - one of these was a Senior Fulbright Scholarship. She teaches American History, American Regionalism (The West of Imagination), the 
Irina CHIRICA

American Short Story, Native American history and culture, Ethnic History and Literature. Her publications include articles and books devoted to aspects of these areas of study.

E-mail: chirica_1@hotmail.com 
